\title{
PRINSIP CHECKS AND BALANCES DALAM SISTEM KETATANEGARAAN INDONESIA
}

\author{
Sunarto \\ Fakultas Ilmu Sosial Universitas Negeri Semarang \\ Kampus UNNES Sekaran Semarang \\ Email: sunarto@gmail.unnes.ac.id
}

\begin{abstract}
In order to avoid a concentration of power tend to arbitrariness, separation of power is needed. One of many separations of power theories is Montesquieu's that divides the state power into legislative, executive, and judicial. So that the three branchs of power are able to control mutually and there is a balance of power, the principle of checks and balances needs to be applied. Indonesian constitutional system after the amendment of UUD 1945 applies such principle where Parliament as the legislature, the President as the executive, and the Supreme Court and the Constitutional Court as a judicial institution can control each other and there is a balance of power among the institutions.
\end{abstract}

Keywords: Separation of Power; Checks and Balances; Arbitrariness.

\begin{abstract}
Abstrak
Menghindari pemusatan kekuasaan yang dapat mengarah pada kesewenang-wenangan, maka perlu diadakan pembagian kekuasaan negara. Salah satu teori pembagian kekuasaan adalah teori Montesquieu yang membagi kekuasaan negara menjadi kekuasaan legislatif, eksekutif, dan yudikatif. Agar tiga bidang kekuasaan tersebut dapat saling mengontrol dan terjadi keseimbangan kekuasaan perlu diterapkan prinsip checks and balances. Sistem ketatanegaraan Indonesia pasca amandemen UUD 1945 menganut prinsip tersebut di mana DPR sebagai lembaga legislatif, Presiden sebagai lembaga eksekutif, dan Mahkamah Agung beserta Mahkamah Konstitusi sebagai lembaga yudikatif dapat saling mengontrol dan terjadi keseimbangan kekuasaan antar lembagalembagatersebut.
\end{abstract}

Kata Kunci: Pembagian Kekuasaan; Checks and Balances; Kesewenang-Wenangan.

\section{A. Pendahuluan}

Distribusi kekuasaan merupakan suatu hal yang penting dalam membangun sistem ketatanegaraan. Distribusi kekuasaan yang baik diharapkan terwujud keseimbangan kekuasaan antara satu lembaga dengan lembaga lainnya dan terdapatnya saling kontrol untuk menghindari terjadinya penyimpangan. Pengalaman sejarah pemerintahan menunjukkan bahwa ketika kekuasaan terpusat pada satu tangan atau satu lembaga tertentu, yang muncul adalah penyimpangan dan berujung pada gerakan rakyat menuntut terjadinya perubahan.

Pengalaman ketatanegaraan di Indonesia menunjukkan betapa ketidakseimbangan kekuasaan telah melahirkan berbagai penyimpangan dalam praktek ketatanegaraan. Presiden sebagai pemegang kekuasaan eksekutif memiliki kekuasaan yang sedemikian besar. Hal itu menjadikan lembaga-lembaga negara lainnya tidak dapat berfungsi dengan baik karena "terkooptasi" oleh kekuasaan eksekutif. Lembaga legislatif yang seharusnya melakukan kontrol atau pengawasan terhadap kekuasaan eksekutif, pengawasan itu tidak dapat berjalan sebagaimana mestinya, sehingga Presiden sebagai pemegang kekuasaan eksekutif dapat mengambil tindakan sekehendaknya. Lembaga legislatif hanya menjadi "rubber stamp" yang memberikan pengabsahan terhadap kebijakan pemerintah. Begitu pula lembaga yudikatif 
yang mestinya menjadi lembaga yang merdeka atau independen untuk mewujudkan keadilan juga kehilangan independensinya karena pengaruh kekuasaan eksekutif.

Berbagai peristiwa yang dikemukakan di atas menyadarkan bahwa pentingnya menghindari adanya kekuasaan negara yang terpusat pada lembaga tertentu dan perlunya saling kontrol antara satu lembaga dengan lembaga lainnya untuk menghindari terjadinya penyimpangan dalam pemerintahan. Berkenaan dengan itu, perwujudan prinsip checks and balances dalam sistem ketatanegaraan merupakan sesuatu yang penting. Oleh karena itu menjadi menarik untuk melakukan pengkajian dengan didasarkan pada permasalahan : bagaimana aspek teoretik pembagian kekuasaan?; bagaimana prinsip checks and balances? dan bagaimana checks and balances dalam sistem ketatanegaraan indonesia?.

\section{B. Pembahasan}

\section{Aspek Teoretik Pembagian} Kekuasaan

Masalah pembagian atau pemisahan kekuasaan telah lama menjadi perhatian dari para pemikir kenegaraan. Pada abad 19 muncul gagasan tentang pembatasan kekuasaan pemerintah melalui pembuatan konstitusi, baik secara tertulis maupun tidak tertulis, selanjutnya tertuang dalam apa yang disebut konstitusi. Konstitusi tersebut memuat batas-batas kekuasaan pemerintah dan jaminan atas hak-hak politik rakyat, serta prinsip check and balances antar kekuasaan yang ada. Pembatasan konstitusi atas kekuasaan negara ini selanjutnya dikenal dengan istilah konstitusionalisme. Konstitusionalisme kemudian memunculkan konsep rechstaat (dari kalangan ahli hukum Eropa Kontinental) atau rule of law (dari kalangan ahli hukum Anglo Saxon) yang di Indonesia diterjemahkan dengan Negara Hukum. ${ }^{1}$

Immanuel Kant dalam pandangannya mengenai negara hukum menyatakan bahwa syarat/ciri negara hukum adalah adanya perlindungan HAM dan pemisahan kekuasaan. Begitu pun Friedrich Julius Stahl menyebutkan pemisahan kekuasaan sebagai salah satu syarat/ciri negara hukum. Ivor Jennings dalam bukunya "The Law and the Constitution ", 2 menyatakan bahwa pemisahan kekuasaan dapat dilihat dari sudut materiil dan formil. Pemisahan kekuasaan dalam arti materiil berarti bahwa pembagian kekuasaan dipertahankan dengan tegas dalam tugastugas kenegaraan yang secara karakteristik memperlihatkan adanya pemisahan kekuasaan itu dalam tiga bagian, yaitu legislatif, eksekutif, dan yudikatif. Sebaliknya, apabila pembagian kekuasaan tidak dipertahankan secara tegas, hal itu disebut pemisahan kekuasaan dalam arti formil. Pemisahan kekuasaan dalam arti materiil sering disebut dengan istilah "separation of power", sedangkan pembagian kekuasaan dalam arti materiil sering disebut "devision of power".

Beberapa teori pembagian kekuasaan yang dikemukakan oleh para tokoh, sebagai berikut:

\section{a. Teori John Locke}

John Locke menyatakan bahwa kekuasaan dalam negara dibagi menjadi 3 (tiga), yaitu legislatif, eksekutif, dan federatif. Kekuasaan legislatif adalah kekuasaan untuk membuat undang-undang, eksekutif adalah kekuasaan untuk melaksanakan undangundang, dan federatif adalah kekuasaan yang berkenaan dengan perang dan damai, membuat perserikatan dan aliansi, serta segala tindakan dengan semua orang dan badan-badan di luar negeri. Adanya kekuasaan federatif yang menyangkut hubungan dengan negara-negara lain dilatarbelakangi oleh keberadaan negara Inggris pada waktu itu, sebagai negara yang memiliki banyak wilayah jajahan.

\section{b. Teori Montesquieu}

Diilhami oleh John Locke dengan teorinya sebagaimana dikemukakan di atas, Montesquieu mengemukakan bahwa dalam pemerintahan negara terdapat 3 (tiga) jenis kekuasaan, yaitu legislatif, eksekutif, dan yudikatif. Kekuasaan legislatif adalah

\footnotetext{
1. Zulkarnain Ridlwan, "Negara Hukum Indonesia Kebalikan Nachtwachterstaat", Fiat Justitia Jurnal Ilmu Hukum, Vol. 5, No. 2, Mei-Agustus 2012, hlm 142.

2. Moh. Kusnardi \& Harmaily Ibrahim, 1983, Pengantar Hukum Tata Negara Indonesia, Jakarta, Penerbit FH UI, hlm 143. 
kekuasaan untuk membuat undang-undang. Kekuasaan eksekutif adalah kekuasaan untuk melaksanakan undang-undang. Kekuasaan yudikatif adalah kekuasaan untuk mengadili pelanggaran terhadap undang-undang. Kekuasaan federatif menurut Montesquieu bukanlah kekuasaan yang berdiri sendiri melainkan bagian dari kekuasaan eksekutif.

Menurut Montesquieu, ketika kekuasaan legislatif dan eksekutif disatukan pada orang atau badan yang sama, maka tidak akan ada lagi kebebasan sebab terdapat bahaya bahwa raja atau badan legislatif yang sama akan memberlakukan undang-undang tirani dan melaksanakannya dengan cara yang tiran pula. ${ }^{3}$ Montesquieu juga menyatakan bahwa ketiga kekuasan itu terpisah satu sama lain, baik mengenai fungsi maupun lembaga yang menyelenggarakannya. ${ }^{4}$ Praktek pemisahan kekuasaan sebagaimana yang dimaksudkan oleh Montesquieu sulit untuk dilaksanakan.

\section{c. Teori Van Vollenhoven}

Menurut Van Vollenhoven, dalam pelaksanaan tugas negara terdapat 4 (empat) fungsi, yaitu regeling (membuat peraturan), bestuur (pemerintahan dalam arti sempit), rechtspraak (mengadili), politie (kepolisian). Di negara modern, tugas pemerintah meliputi tugas negara dalam menyelenggarakan kepentingan umum, kecuali mempertahankan hukum secara preventif (preventive rechtszorg), mengadili, dan membuat peraturan (regeling). Tugas pemerintah bukan sekedar melaksanakan undang-undang dalam rangka penyelenggaraan kepentingan umum. Pada kondisi yang mendesak justru pemerintah harus dapat mengambil tindakan yang cepat untuk menyelesaikan persoalan yang timbul tanpa harus menunggu perintah undang-undang.

\section{d. Teori Logemann}

Menurut Logemann, fungsi kekuasaan negara dapat dibagi menjadi 5 (lima) bidang, yaitu fungsi perundang-undangan (fungsi untuk membuat undang-undang); fungsi pelaksanaan (fungsi melaksanakan undang- undang); fungsi pemerintahan (dalam arti khusus); fungsi kepolisian (fungsi menjaga ketertiban, melakukan penyelidikan dan penyidikan); dan fungsi peradilan (fungsi mengadili pelanggaran terhadap undangundang).

Di antara teori-teori tersebut, yang dijadikan acuan dalam tulisan ini adalah teori yang sudah sangat populer, yaitu teori Montesquieu, yang sering disebut sebagai teori Trias Politica.

\section{Prinsip Checks and Balances}

Prinsip checks and balances merupakan prinsip ketatanegaraan yang menghendaki agar kekuasaan legislatif, eksekutif, dan yudikatif sama-sama sederajat dan saling mengontrol satu sama lain. Kekuasaan negara dapat diatur, dibatasi, bahkan dikontrol dengan sebaik-baiknya, sehingga penyalahgunaan kekuasaan oleh aparat penyelenggara negara ataupun pribadipribadi yang sedang menduduki jabatan dalam lembaga-lembaga negara dapat dicegah dan ditanggulangi. ${ }^{5}$ Mekanisme checks and balances dalam suatu demokrasi merupakan hal yang wajar, bahkan sangat diperlukan. Hal itu untuk menghindari penyalahgunaan kekuasaan oleh seseorang atau pun sebuah institusi, atau juga untuk menghindari terpusatnya kekuasaan pada seseorang ataupun sebuah institusi, karena dengan mekanisme seperti ini, antara institusi yang satu dengan yang lain akan saling mengontrol atau mengawasi, bahkan bisa saling mengisi. ${ }^{6}$

Prinsip tersebut mulanya merupakan prinsip yang diterapkan dalam sistem ketatanegaraan Amerika Serikat, di mana sistem ketatanegaraan dimaksud memadukan antara prinsip pemisahan kekuasaan dan prinsip checks and balances. Kekuasaan negara dibagi atas kekuasaan legislatif, eksekutif, dan yudikatif, yang masing-masing dipegang oleh lembaga yang berbeda tanpa adanya kerjasama satu sama lain, sedangkan dengan checks and balances, antara satu lembaga dan lembaga lainnya terdapat keseimbangan kekuasaan dan mekanisme

\footnotetext{
3. CF. Strong, 2008, Konstitusi-konstitusi Politik Modern, Bandung, Nusa Media, hlm 330.

4 Sofyan Hadi, "Fungsi Legislasi Dalam Sistem Pemerintahan Presidensil (Studi Perbandingan Indonesia . dan Amerika Serikat)", Jurnal Ilmu Hukum DIH, Vol. 9, No. 18, Februari 2013, hlm. 78

5. Jimly Asshiddiqie, 2010, Konstitusi dan Konstitusionalisme Indonesia, Jakarta, Sinar Grafika, hlm 61.

6. Afan Gaffar, 2006, Politik Indonesia: Transisi Menuju Demokrasi, Yogyakarta, Pustaka Pelajar, hlm 89.
} 
saling kontrol. Prinsip checks and balances tidak dapat dipisahkan dari masalah pembagian kekuasaan. Sebagamana ditulis oleh Robert Weissberg, ${ }^{7}$ "A principle related to separation of powers is the doctrine of checks and balances. Whereas separation of powers devides governmental power among different officials, checks and balances gives each official some power over the others.

Di Amerika Serikat, sebagai perwujudan prinsip checks and balances, Presiden diberi wewenang untuk memveto rancangan undang-undang yang telah diterima oleh Congress, akan tetapi veto ini dapat dibatalkan oleh Congress dengan dukungan 2/3 suara dari kedua Majelis. Mahkamah Agung mengadakan check terhadap badan eksekutif dan badan legislatif melalui judicial review. Di lain pihak, hakim agung yang oleh badan eksekutif diangkat seumur hidup dapat diberhentikan oleh Congress jika ternyata melakukan tindakan kriminal. Presiden dapat di-impeach oleh Congress. Presiden boleh menandatangani perjanjian internasional, tetapi baru dianggap sah jika senat juga mendukungnya. Begitu pula untuk pengangkatan jabatan-jabatan yang menjadi kewenangan presiden, seperti hakim agung, duta besar, diperlukan persetujuan dari Senat. Sebaliknya, menyatakan perang (yang merupakan tindakan eksekutif) menjadi kewenangan Congress. ${ }^{8}$

Prinsip checks and balances ini dapat dioperasionalkan melalui cara-cara, sebagai berikut: ${ }^{9}$

a. Pemberian kewenangan untuk melakukan tindakan kepada lebih dari satu lembaga. Misalnya kewenangan pembuatan undang-undang diberikan kepada pemerintah dan parlemen;

b. Pemberian kewenangan pengangkatan pejabat tertentu kepada lebih dari satu lembaga, misalnya eksekutif dan legislatif;

c. Upaya hukum impeachment lembaga yang satu terhadap lembaga lainnya; d. Pengawasan langsung dari satu lembaga terhadap lembaga negara lainnya, seperti eksekutif diawasi oleh legislatif;

e. Pemberian kewenangan kepada pengadilan sebagai lembaga pemutus perkara sengketa kewenangan antara lembaga eksekutif dan legislatif.

\section{Checks and Balances dalam Sistem} Ketatanegaraan Indonesia

Pengalaman ketatanegaraan Indonesia menunjukkan bahwa banyaknya penyimpangan kekuasaan pada masa lalu secara yuridis disebabkan oleh besarnya kekuasaan Presiden yang diberikan oleh UUD 1945 (sebelum amandemen). Sesuai ketentuan UUD 1945, Presiden memiliki kekuasaan yang sangat luas. Di samping kekuasaan di bidang eksekutif, Presiden juga memilki kekuasaan di bidang legislatif dan yudikatif. Analisis ketatanegaraan menunjukkan bahwa UUD 1945 membawa sifat executive heavy, artinya memberikan bobot kekuasaan yang lebih besar kepada lembaga eksekutif, yaitu Presiden.

Menurut Mahfud MD, salah satu kelemahan dari UUD 1945 sebelum amandemen adalah tidak adanya mekanisme checks and balances. Presiden menjadi pusat kekuasaan dengan berbagai hak prerogatif. Selain menguasai bidang eksekutif, Presiden memiliki setengah dari kekuasaan legislatif yang dalam prakteknya Presiden juga menjadi ketua legislatif. Presiden dalam kegentingan yang memaksa juga berhak mengeluarkan PERPU, tanpa kriteria yang jelas tentang apa yang dimaksud "kegentingan yang memaksa". UUD 1945 juga tidak mengatur mekanisme judicial review, padahal seringkali lahir produk legialatif yang dipersoalkan konsistensinya dengan UUD karena lebih banyak didominasi oleh keinginan-keinginan politik dari pemerintah. ${ }^{10}$

Sistem ketatanegaraan Indonesia, setelah perubahan UUD 1945 menganut prinsip checks and balances. Prinsip ini dinyatakan secara tegas oleh MPR sebagai

7. Robert Weissberg, 1979, Understanding American Government, New York, Holt Rinehart and Winston, hlm 35.

8. Miriam Budiardjo, 2010, Dasar-dasar Ilmu Politik, Edisi Revisi, Jakarta, PT. Gramedia Pustaka Utama, hlm 284.

9. Munir Fuady, 2009, Teori Negara Hukum Modern, Bandung, Refika Aditama, hlm 124.

Moh. Mahfud MD, 2000, Demokrasi dan Konstitusi di Indonesia: Studi tentang Interaksi Politik dan Kehidupan

10. Ketatanegaraan, Jakarta, Rineka Cipta, hlm 147. 
salah satu tujuan perubahan UUD 1945, yaitu menyempurnakan aturan dasar penyelenggaraan negara secara demokratis dan modern, melalui pembagian kekuasaan, sistem saling mengawasi dan saling mengimbangi (checks and balances) yang lebih ketat dan transparan. ${ }^{11}$ Suatu pendapat menyatakan bahwa salah satu tujuan perubahan UUD NRI Tahun 1945 adalah untuk menyempurnakan aturan dasar penyelenggaraan negara secara demokratis dan modern, antara lain melalui pembagian kekuasaan yang lebih tegas, sistem saling mengawasi dan saling mengimbangi (check and balances) yang lebih ketat dan transparan, dan pembentukan lembagalembaga negara yang baru untuk mengakomodasi perkembangan kebutuhan bangsa dan tantangan zaman. ${ }^{12}$

Hubungan antara kekuasaan legislatif, eksekutif, dan yudikatif di Indonesia dapat digambarkan, sebagai berikut:

a. Hubungan antara legislatif dan eksekutif

Keseimbangan antara kekuasaan legislatif dan eksekutif telah diletakkan landasannya secara konstitusional dalam UUD 1945 setelah amandemen. UUD 1945 hasil amandemen tidak lagi menempatkan lembaga MPR sebagai lembaga tertinggi negara yang memilih Presiden dan Wakil Presiden. Artinya, tidak ada lembaga dalam negara yang memiliki posisi di atas lembaga yang lain. MPR bukan lagi berada di atas Presiden, dan Presiden bukan lagi mandataris MPR yang kedudukannya sangat tergantung pada MPR. Melalui amandemen UUD 1945 telah terbangun sistem ketatanegaraan yang membawakan sifat egalitarian di antara lembaga-lembaga negara yang ada. Sebab, ketika ada lembaga yang memiliki kedudukan tertinggi, berarti secara yuridis konstitusional lembaga tersebut berhak melakukan tindakan apa saja tanpa dapat dikontrol oleh lembaga yang lain. Hal ini kurang sesuai dengan jiwa demokrasi yang mengandung nilai kesetaraan, dalam hal ini adalah kesetaraan di antara lembaga-lembaga negara di dalamnya.

Antara DPR dan Presiden terdapat hubungan yang secara garis besar dapat nyatakan dalam dua hal, yaitu hubungan yang bersifat kerjasama, dan hubungan yang bersifat pengawasan. Kedua lembaga itu harus bekerjasama dalam pembuatan undangundang, termasuk Undang-Undang APBN. Melalui amandemen UUD 1945, kewenangan membuat undang-undang telah diletakkan pada porsi yang sesuai, yaitu DPR. Hal yang masih perlu menjadi perhatian adalah bagaimana agar dalam praktek, DPR lebih berperan dalam pengajuan rancangan undang-undang. Sebab selama ini inisiatif untuk membuat rancangan undang-undang hampir semuanya datang dari pemerintah atau Presiden.

Hubungan antara Presiden dan DPR yang bersifat pengawasan, tampak bahwa pengawasan yang dilakukan oleh DPR terhadap kebijakan pemerintah telah berjalan lebih baik dibandingkan dengan era sebelumnya. Bahkan pengawasan tersebut kadang-kadang terkesan berlebihan di mana DPR mempersoalkan kebijakan pemerintah yang semestinya tidak perlu dipersoalkan. Di sisi lain, dalam hal-hal tertentu pengawasan itu tidak ada tindak lanjut yang jelas.

b. Hubungan antara eksekutif dan yudikatif.

Titik simpul dalam hubungan antara eksekutif dan yudikatif terletak pada kewenangan Presiden untuk melakukan tindakan dalam lapangan yudikatif, seperti memberi grasi, amnesti, abolisi, dan rehabilitasi. Amandemen UUD 1945 juga telah memberikan landasan bagi terwujudnya keseimbangan itu, di mana untuk memberikan grasi dan rehabilitasi Presiden harus memperhatikan pertimbangan Mahkamah Agung, dan untuk memberikan a m e st i dan abolis i harus mempertimbangkan pertimbangan DPR. Hal ini merupakan pengurangan atas kekuasaan Presiden menurut UUD 1945 (sebelum amandemen), yang sering dikatakan sebagai kekuasaan yang terlalu berat pada eksekutif (executive heavy).

c. Hubungan antara legislatif dan yudikatif.

Hubungan antara legislatif dan yudikatif terkait bagaimana keberadaan dua lembaga

\footnotetext{
11.Hamdan Zoelva, 2011, Pemakzulan Presiden di Indonesia, Jakarta, Sinar Grafika, hlm 64.

12.Pataniari Siahaan, 2012, Politik Hukum Pembentukan Undang-undang Pasca Amandemen UUD 1945, Jakarta, Konstitusi Press, hlm 264.
} 
itu berperan mewujudkan sistem perundangundangan yang isinya tidak bertentangan dengan peraturan yang lebih tinggi. Undangundang sebagai salah satu bentuk peraturan perundang-undangan adalah produk lembaga legislatif. Di pihak lain, ada kewenangan Mahkamah Konstitusi untuk menguji undang-undang terhadap UUD 1945, yang memungkinkan ketentuan dalam undangundang dinyatakan tidak sah karena bertentangan dengan UUD. Ini berarti Mahkamah Konstitusi juga memiliki kewenangan di bidang legislatif dalam pengertian negatif (negative legislation).

Dengan adanya kewenangan tersebut dalam proses pembentukan dan perumusan materi atau substansi undang-undang, DPR dan Presiden harus mewaspadai kemungkinan adanya judicial review dari Mahkamah Konstitusi. ${ }^{13}$ Sebagaimana dikemukakan Moh. Mahfud MD, pelembagaan judicial review diperlukan karena undang-undang itu adalah produk politik yang pasti tidak steril dari kepentingan politik anggota-anggota lembaga yang membuatnya. Produk politik bisa saja memuat isi yang lebih sarat dengan kepentingan politik kelompok dan jangka pendek yang secara substansial bertentangan dengan peraturan yang lebih tinggi hierarkhinya. ${ }^{14}$

Persoalan yang muncul dalam hal ini adalah seberapa jauh kewenangan Mahkamah Konstitusi dalam rangka menguji undangundang terhadap UUD. Apakah kewenangan Mahkamah Konstitusi sebatas menyatakan isi pasal tertentu dalam undang-undang bertentangan dengan UUD, ataukah Mahkamah Konstitusi juga berwenang menentukan rumusan pasal sebagai koreksi atas pasal yang dianggap bertentangan itu.

Menurut Pasal 57 UU No. 24 Tahun 2003 sebagaimana telah diubah dengan UU No. 8 Tahun 2011 tentang Mahkamah Konstitusi, bahwa putusan Mahkamah Konstitusi yang amar putusannya menyatakan bahwa materi muatan ayat, pasal, dan/atau bagian undang-undang bertentangan dengan Undang-Undang Dasar Negara
Republik Indonesia Tahun 1945, materi muatan ayat, pasal, dan/atau bagian undangundang tersebut tidak mempunyai kekuatan hukum mengikat. Mengingat kewenangan membuat undang-undang ada pada DPR bersama pemerintah, maka kewenangan Mahkamah Konstitusi sebatas memutus bahwa isi undang-undang bertentangan dengan UUD. Kewenangan membuat rumusan baru dari isi undang-undang tersebut tetap menjadi kewenangan lembaga legislatif.

Keseimbangan kekuasaan antara lembaga yudikatif, legislatif dan eksekutif juga dibangun di atas prosedur pengisian hakim-hakim, baik hakim Mahkamah Agung maupun hakim Mahkamah Konstitusi. Pengisian hakim hakim agung dilakukan melalui seleksi yang dilakukan oleh Komisi Yudisial. Hasil seleksi Komisi Yudisial diajukan kepada DPR untuk dibahas dan dimintakan persetujuan. Calon-calon yang telah disetujui oleh DPR diangkat menjadi hakim agung melalui Keputusan Presiden. Sedangkan hakim Mahkamah Konstitusi yang jumlahnya 9 (sembilan) orang terdiri dari 3 (tiga) orang hakim diajukan oleh DPR, 3 (tiga) orang diajukan oleh Presiden, dan 3 (tiga) orang diajukan oleh Mahkamah Agung. Komposisi semacam ini menggambarkan keseimbangan lembaga legislatif, eksekutif, dan yudikatif dalam membangun peran Mahkamah Konstitusi.

\section{Simpulan}

Upaya mewujudkan checks and balances dalam sistem ketatanegaraan Indonesia telah dilakukan melalui amandemen UUD 1945. Tidak ada lagi lembaga yang diposisikan sebagai lembaga tertinggi negara. Melalui amandemen tersebut, Presiden dipilih secara langsung oleh rakyat sehingga memiliki kedudukan yang kuat. Kewenangan utama pembuatan undang-undang ada pada DPR, walaupun persetujuan Presiden diperlukan. Ketika rancangan undang-undang telah disetujui oleh DPR bersama Pemerintah tetapi sampai batas waktu tiga puluh hari tidak disahkan oleh Presiden, maka rancangan undang-

\footnotetext{
13. Saldi Isra, 2010, Pergeseran Fungsi Legislasi: Menguatnya Model Legislasi Parlementer dalam Sistem Presidensial Indonesia, Jakarta, PT. Raja Grafindo Persada, hlm 10.

14. Moh. Mahfud MD, 2011, Membangun Politik Hukum, Menegakkan Konstitusi, Jakarta, Rajawali Press, hlm 37.
} 
undang itu sah menjadi undang-undang dan wajib diundangkan. Undang-undang yang dibuat oleh DPR bersama Presiden dapat dikoreksi oleh Mahkamah Konstitusi melalui mekanisme judicial review. Akhirnya, ketika terjadi sengketa kewenangan antar lembaga negara, Mahkamah Konstitusi yang berwenang memutuskan.

\section{Daftar Pustaka}

Asshiddiqie Jimly, 2005, Format Kelembagaan Negara dan Pergeseran Kekuasaan dalam UUD 1945, Yogyakarta, FH UII Press.

Budiardjo Miriam, 2010, Dasar-dasar Ilmu Politik (Edisi Revisi), Jakarta, PT. Gramedia Pustaka Utama.

Fuady Munir, 2009, Teori Negara Hukum Modern, Bandung, Refika Aditama.

Gaffar Afan, 2006, Politik Indonesia: Transisi Menuju Demokrasi, Yogyakarta, Pustaka Pelajar.

Hadi Sofyan, "Fungsi Legislasi Dalam Sistem Pemerintahan Presidensil (Studi Perbandingan Indonesia dan Amerika Serikat)", Jurnal Ilmu Hukum DIH, Vol. 9, No. 18, Februari 2013.

Isra Saldi, 2010, Pergeseran Fungsi Legislasi: Menguatnya Model Legislasi Parlementer dalam Sistem Presidensial Indonesia, Jakarta, PT. Raja Grafindo Persada.

Kusnardi Moh. \& Ibrahim, Harmaily, 1983, Pengantar Hukum Tata Negara Indonesia, Jakarta, Penerbit FH UI.

Mahfud MD Moh, 2000, Demkrasi dan Konstitusi di Indonesia: Studi tentang Interaksi Politik dan Kehidupan Ketatanegaraan, Jakarta, Rineka Cipta.

Mahfud MD Moh, 2011, Membangun Politik Hukum, Menegakkan Konstitusi, Jakarta, Rajawali Press.

Ridlwan Zulkarnain, "Negara Hukum I n d o n e s i a $\mathrm{K}$ e b a $1 \mathrm{ik}$ a $\mathrm{n}$ Nachtwachterstaat", Fiat Justitia Jurnal Ilmu Hukum, Vol. 5, No. 2, Mei-Agustus 2012.

Siahaan Pataniari, 2012, Politik Hukum Pembentukan Undang-Undang Pasca Amandemen UUD 1945, Jakarta, Konstitusi Press
Strong CF, 2008, Konstitusi-konstitusi Politik Modern, Bandung, Nusa Media.

Weissberg Robert, 1979, Understanding American Government, New York, Holt Rinehart and Winston.

Zoelva Hamdan, 2011, Pemakzulan Presiden di Indonesia, Jakarta, Sinar Grafika

Undang-Undang Dasar Negara Republik Indonesia Tahun 1945

Undang-Undang Nomor 8 Tahun 2011 Tentang Mahkamah Konstitusi

Undang-Undang Nomor 24 Tahun 2003 Tentang Mahkamah Konstitusi 